\title{
Available Macro Nutrient Status and their Relationship with Soil Physico- Chemical Properties of Mirzapur District of Uttar- Pradesh, India
}

\author{
P.K. Bharteey, Y.V. Singh*, P.K. Sharma Sukirtee, Maneesh Kumar and \\ Avinash Kumar Rai
}
Department of Soil Science and Agricultural Chemistry, Institute of Agricultural Sciences, Banaras Hindu University, and Varanasi - 221005
*Corresponding author

\begin{tabular}{|c|c|}
\hline & A B S T R A C T \\
\hline Keywords & $\begin{array}{l}\text { Soil fertility evaluation of an area is an important aspect in context of sustainable } \\
\text { agriculture production. The macro nutrients govern the fertility of soils and control }\end{array}$ \\
\hline $\begin{array}{l}\text { Macronutrient, } \\
\text { Physico-chemical } \\
\text { properties, } \\
\text { Correlation, } \\
\text { Narayanpur block } \\
\text { Mirzapur. }\end{array}$ & $\begin{array}{l}\text { the growth and yields of crops. In the present investigation Narayanpur block was } \\
\text { selected in the district Mirzapur of Uttar Pradesh and studied the available } \\
\text { macronutrient status and their relationship with physico-chemical properties. } \\
\text { Mirzapur district have different cropping systems and irrigated by Ganga canal } \\
\text { and Tube well tributaries. Seven representative villages were chosen and } 10\end{array}$ \\
\hline Article Info & $\begin{array}{l}\text { surface soil }(0-15 \mathrm{~cm}) \text { samples collected from each village and analyzed for } \\
\text { physico-chemical properties and available } \mathrm{N}, \mathrm{P}, \mathrm{K} \text {, and } \mathrm{S} \text { status using standard }\end{array}$ \\
\hline $\begin{array}{l}\text { Accepted: } \\
\text { 29 June } 2017 \\
\text { Available Online: } \\
\text { 10 July } 2017\end{array}$ & $\begin{array}{l}\text { laboratory procedures. Results of the study indicated that soils of Narayanpur } \\
\text { block were Medium to High in organic carbon. Out of } 75 \text { collected soil samples, } \\
96 \% \text { were Low in available nitrogen and medium to high in available phosphorus, } \\
\text { potassium and Sulphur Medium to high in soil. }\end{array}$ \\
\hline
\end{tabular}

\section{Introduction}

In developing countries like India, where land-person ratio is rapidly narrowing, the only means of meeting the needs of agricultural produce is through increased productivity without detriment to environment and sustainability. Soil characterization in relation to evaluation of fertility status of soils of an area is an important context of sustainable agriculture production. Nitrogen, phosphorus, potassium, and Sulphur are important soil nutrients which control the fertility and yield of the crops. Because of imbalanced and inadequate fertilizer use coupled with low efficiency of other inputs, the Response Efficiency of chemical fertilizer nutrients has declined tremendously under intensive agriculture in recent years. Variation in nutrient supply is natural phenomenon and some of them may be sufficient where others may be deficient. According to (Lal and Singh), fertility encompasses physical, chemical and biological degradation process. This is prerequisite for determining appropriate conservation activities in monitoring our natural resource base. With the advances in 
information technology the data on soils, weather and other data can be integrated in making such decisions (Das, 1999). The stagnation in crop productivity cannot be boosted without judicious use of macro and micronutrient fertilizers to overcome existing imbalances or deficiencies.

Uttar Pradesh, the fourth largest State in the country in terms of geographical area, is located in the northwestern part of the country. It has a geographical area of 243,290 square kilometer, which constitute $7.33 \%$ area of the country and $16.50 \%$ of national population (Census, 2011 Provisional data). The prospects of agriculture in the State largely depend on timely arrival of monsoon. Where rainfall pattern indicates that during the current monsoon season, the State has received $650 \mathrm{~mm}$ rainfall in southwest monsoon and $1000 \mathrm{~mm}$ southeastern against the normal rainfall of $741 \mathrm{~mm}$. where soils are having low to medium soil fertility, low to medium water holding capacity, medium infiltration rate and shallow in depth in some areas (Mathur and Yadav, 2006). 1368960 hectare area is under problematic soils (saline and alkaline).

Due to scarcity of rainfall there is limited availability of ground water. The crops suffer medium to high temperature. The water holding capacity is inadequate in lighter soils. The nitrogen and organic carbon status of the soils, in general is medium. The soils are well supplied with potassium. Micro elemental deficiencies particularly zinc and Sulphur has also been observed in pockets. Present investigation was useful in judging the deficiency of various nutrients and thereby use of fertilizers depending on their status. The present study was conducted to recognize the status of macronutrient and their relationship with physico-chemical properties in the soils of Narayanpur block district Mirzapur (U.P).

\section{Materials and Methods}

\section{Study area}

Mirzapur is an Eastern most district of Uttar Pradesh state in North India. The town of Mirzapur is the district headquarters and located between Geographical area of Mirzapur is $4521 \mathrm{~km}^{2}$ (latitude $23^{0} 52^{\prime \prime}$ to $25^{0}$ $32^{\prime \prime} \mathrm{N}$ and longitude $82^{0} 72^{\prime \prime}$ to $\left.83^{\circ} \quad 33^{\prime \prime} \mathrm{E}\right)$. Mirzapur is situated at the point where the side of Ganga river. Narayanpur block is one of the four tehsil of Mirzapur district, located Eastern-western area. The climate of Narayanpur block is marked by with large variation of temperature, where mean monthly maximum temperature during summer months (May to July) reaches up to $47^{\circ} \mathrm{C}$ and minimum temperature during winter months (December and January) sometimes goes as low as $0^{\circ} \mathrm{C}$ or even less. The Mean annual rainfall is $750 \mathrm{~mm}$. The region is irrigated by the Ganga River and Channel Dams. Major crops (Table 1) of the region are Rice, wheat, Groundnut, Soyabean, grams, barely and sugarcane and Horticultural crop like fruits, vegetable, and flowers. Industries in Mirzapur district are based on agriculture.

\section{Soil sampling and analysis}

Surface soil of the farmer's field from different villages of Narayanpur block of Narayanpur district, were sampled randomly to a depth of $0-15 \mathrm{~cm}$ in $\mathrm{V}$ shape with the help of Khurpi. Each soil sample was mixed thoroughly and about a half kilogram of composite sample from farmer's fields was analyzed. The physical properties of soil viz. bulk density by core method, particle density by pycnometer method and porosity was measured following the procedure ofKlute and Dirksen. Soil $\mathrm{pH}$ and electrical conductivity (EC) of the soil samples in soil: water suspension (1:2.5) was measured using a glass electrode in a digital $\mathrm{pH}$ meter and 
systronics electrical conductivity meter, respectively. Organic carbon was determined by wet digestion method of Walkley and Black, available Nitrogen by Alkaline permanganate method, Available Phosphorus by colorimetric method using sodium bicarbonate, Available Potassium by ammonium acetate extraction method, Available Sulphur by turbidimetric method.

\section{Statistical analysis}

The relationship between different soil characteristics and macronutrient contents in soils were determined using correlation coefficients formula

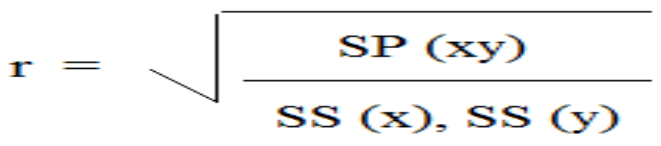

$r=$ Correlation coefficient

$\mathrm{SP}(\mathrm{xy})=$ Sum product of $\mathrm{x}$, $\mathrm{y}$ variables

SS $(x)=$ Sum of square of $x$ variable

SS $(y)=$ Sum of square of y variable.

\section{Results and Discussion}

\section{Physico-chemical properties of soil}

Physico-chemical properties of Soil The data on $\mathrm{pH}, \mathrm{EC}$, B.D., P.D. and organic carbon are presented in table 2 which revealed that the $\mathrm{pH}$ of soils ranged varies 6.4 to 8.2, with average value of 7.5. Absence of luxuriant vegetation further decreases level of organic matter in these soils. It is expected that a decrease in rainfall or Increase in the $\mathrm{pH}$ due to precipitation of $\mathrm{CaCO}_{3}$ and also increases soil $\mathrm{pH}$. The soils of Narayanpur block were neutral to moderately alkaline in reaction. This might be due to medium to high base saturation of soils. Kumar and Babel (2011), Sharma et al., (2013) and Nigam et al., (2014) Singh et al., (2015) also recorded similar findings.
The electrical conductivity of Narayanpur block (Table 2) varied from 0.11 to $0.32 \mathrm{dS}$ $\mathrm{m}^{-1}$ with an average value of $0.18 \mathrm{dS} \mathrm{m}^{-1}$. The values indicated that salinity is not a problem in these soils. Similar result was observed by Sharma et al., (2013) and Kumar and Babel (2011).

Bulk density and Particle density ranged from 1.09 to 1.41 and 2.04 to $2.70 \mathrm{Mg} \mathrm{m}^{-3}$ respectively with a mean value of 1.28 and $2.40 \mathrm{Mg} \mathrm{m}^{-3}$ the results are confirmatory with results obtained by Pranagal and Chmielowski in soils of South-Eastern Poland (2012).

Estimates of organic carbon are used to assess the amount of organic matter in soils. Soil organic matter content can be used as an index of $\mathrm{N}$ availability because the $\mathrm{N}$ content in soil organic matter is relatively constant. The data on percent organic carbon content ranged between 0.14 to 0.86 percent with a mean value of 0.42 percent (Table 2), Thus majority of the soil samples of Narayanpur block were Low to medium in their organic matter status. The high temperatures prevailing in the area might be responsible for rapid decomposition of organic matter. These findings are in agreement with the results reported by Sharma et al., (2013) in soils under continuous vegetable based cropping systems at Indian Institute of Vegetable Research, Varanasi.

\section{Status of available primary macronutrients in soil}

The status of $\mathrm{N}, \mathrm{P}$ and $\mathrm{K}$ has been shown in tables 3, 4 and 5. Available nitrogen content of these soils ranged between 131.71 to $332.00 \mathrm{~kg} \mathrm{ha}^{-1}$ with a mean value of $188.02 \mathrm{~kg}$ $\mathrm{ha}^{-1}$. On the basis of the ratings suggested by Muhr et al., (1965) 96\% of the soil samples were found to be low $\left(<280 \mathrm{~kg} \mathrm{~N} \mathrm{ha}^{-1}\right)$ and remaining $4 \%$ in the category of medium (280 to $560 \mathrm{~kg} \mathrm{~N} \mathrm{ha}^{-1}$ ) (Table 5). Most of the 
sample was shown the medium availability of nitrogen. The availability of nitrogen is not only an essential part of carbohydrates, fats and oils but also an essential ingredient of proteins. The available nitrogen is an important factor to increase the soil fertility. Low nitrogen status in the soils could be due to low amount of organic carbon in the soils and uncertain rainfall has a major impact on availability of nitrogen. Similar results were observed by Verma et al., (2005) and Singh et al., (2015).

The available phosphorous content in these soils varied from 10.46 to $64.39 \mathrm{~kg} \mathrm{ha}^{-1}$ with a mean value of $25.79 \mathrm{~kg} \mathrm{ha}^{-1}$, On the basis of the limits suggested to Muhr et al., (1965) most of the soil samples $(46.66 \%)$ were medium (12.5 to $25 \mathrm{~kg} \mathrm{P}^{-1}$ ) in available phosphorus status and 52\% were under high ( $\mathrm{P}>25 \mathrm{Kgha}^{-1}$ ) category. It is a constituent of the cell nucleus, essential for cell division and the development of meristematic tissues at the growing points. It makes 0.1 to $0.5 \%$ of dry weight of the plant. According to Gupta et al., (2006) the normal value of phosphorus in soil should be (12.5 to $\left.25 \mathrm{~kg} \mathrm{ha}^{-1}\right)$. Higher Phosphorus may be due to fixed phosphorus pool of phosphate contains inorganic phosphate compounds that are very insoluble and organic compounds that are resistant to mineralization by microorganisms in soil. These findings are in agreement with the results reported by Meena et al., (2006) in soil of Tonk district of Rajasthan.

Status of available potassium content in these soils ranged from 112.00 to $806.4 \mathrm{~kg} \mathrm{ha}^{-1}$ with a mean value of $299.15 \mathrm{~kg} \mathrm{ha}^{-1}$. According to Muhr et al., (1965) out of 75 soil samples, $62.66 \%$ soil samples were found under medium (135 to $335 \mathrm{~kg} \mathrm{~K} \mathrm{ha}^{-1}$ ) range and $33.34 \%$ soil samples under high $(>335 \mathrm{~kg} \mathrm{~K}$ ha $^{-1}$ ) available $\mathrm{K}$ minerals. Pulakeshi et al., (2012) observed similar results from soils in Mantagani village of North Karnataka.

\section{Status of available secondary macronutrient}

The data on status of available $S$, in soils of Narayanpur block of Sri Narayanpur district are presented in tables 3, 4 and 5. The available sulphur content in soils of Narayanpur block ranged from 12.8 to 30.5 $\mathrm{kg} \mathrm{ha}^{-1}$ with an average value of $22.43 \mathrm{~kg} \mathrm{ha}^{-1}$. Plant roots absorb sulphur in the form of $\mathrm{SO}^{-}$ 2 from the soil solution. Keeping this fact in view, the soil under study may be classified as deficient $\left(20 \mathrm{~kg} \mathrm{~S} \mathrm{ha}^{-1}\right)$ category as per the categorization given by Muhr et al., (1965) According to these categories, $29.34 \%$ samples were found under medium and remaining $66.66 \%$ samples were found under high category. Thus, the soils of Narayanpur block of district Mirzapur are likely to well respond to Sulphur fertilization. High available sulphur in these soils is due to sulphur bearing minerals. These results are comparable with those reported by Giri et al., (2002) Singh and Mishra (2012).

\section{Correlation between physico-chemical properties and available macro nutrients in the soils of Narayanpur block}

The data on correlation between soil properties and available nutrients in top soil of Narayanpur block are presented in table 6 revealed the soil Nitrogen was found Nonsignificant correlation with $\mathrm{pH}(\mathrm{r}=.048), \mathrm{EC}$ $(\mathrm{r}=.195)$, Bulk density $(\mathrm{r}=.078)$, and Organic Carbon $(\mathrm{r}=.022)$, the Nitrogen in soil negatively Non-Significant with Particle density comparable with the relationship reported by Somasundaram et al., (2013) and Kartikeyan et al., (2014).

Available phosphorus were found Negatively Non significant correlation with Bulk density $(\mathrm{r}=-.174)$, Particle density ( $\mathrm{r}=-.195)$, Organic Carbon ( $\mathrm{r}=-.155)$. 
Table.1 Description of sampling sites

\begin{tabular}{ccc}
\hline S.N. & Village Name & Cropping pattern \\
\hline 1. & Nakahara & Groundnut-Potato, Rice-Potato, Groundnut-Pea \\
2. & Raipuriya & Groundnut-Wheat, Rice-Wheat, Groundnut-Pea \\
3. & JalalpurMaafi & Groundnut-Potatoes, Bajra-Wheat, Soyabean-Potato \\
4. & Dixitpur & Rice-Wheat-Mustard, Bajra-Sugarcane, Groundnut-Potato \\
5. & Kailahat & Groundnut-Pea-Mustard, Soyabean-Potato, Rice-Wheat \\
6. & Bagahi & Groundnut-Potato, Rice-Potato, Groundnut-Pea \\
7. & Kolana & Rice-Wheat-Mustard, Rice-Sugarcane, Bajra-Wheat \\
\hline
\end{tabular}

Table.2 Physico-chemical properties of soils of Narayanpur block

\begin{tabular}{ccccc}
\hline Soi characteristics & Range & \multicolumn{1}{c}{ Mean } & S.D & \\
\hline 1. & 0.48 & $\mathrm{pH}(1: 2.5)$ & $6.4-8.2$ & 7.5 \\
2. & 0.04 & E.C. $(\mathrm{dS} \mathrm{m}-1)$ & $0.11-0.32$ & 0.18 \\
3. & & B.D. $\left(\mathrm{mg}^{-3}\right)$ & $1.09-1.141$ & 1.28 \\
4.076 & & P.D. $\left(\mathrm{mg}^{-3}\right)$ & $2.04-2.70$ & 2.40 \\
\hline
\end{tabular}

Table.3 Status of available macronutrients viz. available N, P, K, and S in soils of Narayanpur block

\begin{tabular}{cccc}
\hline Soil characteristics & Range & Mean & S.D. \\
\hline 1. Available $\mathrm{N}\left(\mathrm{kg} \mathrm{ha}^{-1)}\right.$ & $131.71-332$ & 188.02 & 37.65 \\
2. Available $\mathrm{P}\left(\mathrm{kg} \mathrm{ha}^{-1}\right)$ & $10.71-64.39$ & 25.79 & 9.07 \\
3. Available $\mathrm{K}\left(\mathrm{kg} \mathrm{ha}^{-1}\right)$ & $112-806.4$ & 299.15 & 133.5 \\
4. Available $\mathrm{S}\left(\mathrm{kg} \mathrm{ha}^{-1}\right)$ & $6.51-39.06$ & 23.25 & 8.80 \\
\hline
\end{tabular}

Table.4 Rating limits for soil test values used in India (Muhret al., 1965)

\begin{tabular}{cccc}
\hline NutrientsRating of the soil test values & Low & Medium & High \\
& & & \\
\hline Organic carbon (\%) & $<0.5$ & $0.5-0.75$ & $>0.75$ \\
Available $\mathrm{N}\left(\mathrm{kg} \mathrm{ha}^{-1}\right)$ & $<280$ & $280-560$ & $>560$ \\
Available $\mathrm{P}\left(\mathrm{kg} \mathrm{ha}^{-1}\right)$ & $<12.5$ & $12.5-25$ & $>25$ \\
Available $\mathrm{K}\left(\mathrm{kg} \mathrm{ha}^{-1}\right)$ & $<135$ & $135-335$ & $>335$ \\
Available $\mathrm{S}\left(\mathrm{kg} \mathrm{ha}^{-1}\right)$ & $<10$ & $10-20$ & $>20$ \\
\hline
\end{tabular}


Fig.1 Location of Narayanpur block in Mirzapur district.

Correlation between physico-chemical properties and available macro nutrients in the soils of Narayanpur block

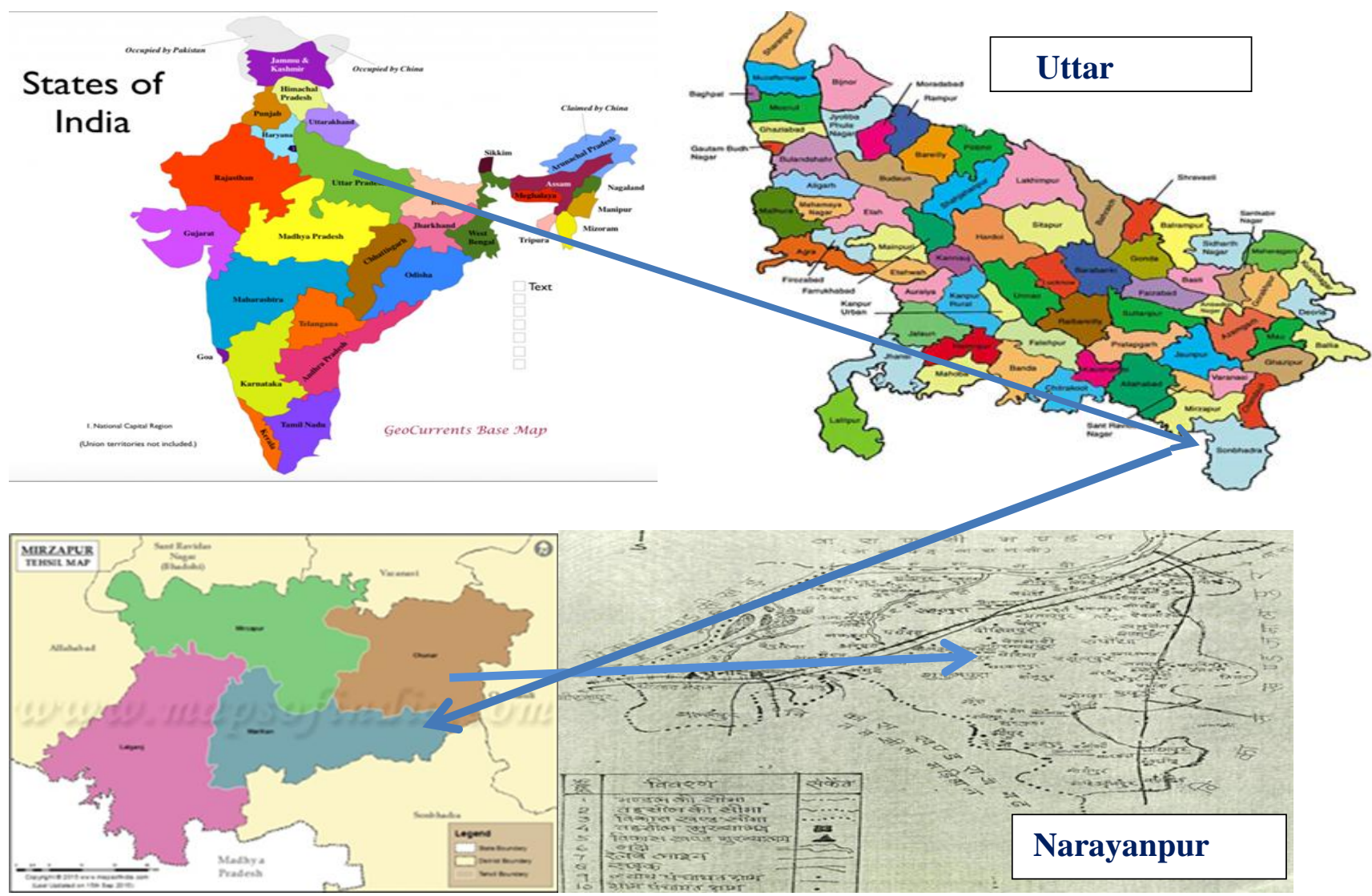

Table.5 Classification OC\% and available Macro nutrients status content in soils of Narayanpur block

\begin{tabular}{lllccrr}
\hline S.No Elements & $\begin{array}{c}\text { No of } \\
\text { Samples }\end{array}$ & $\begin{array}{l}\% \text { of } \\
\text { samples }\end{array}$ & $\begin{array}{c}\text { No of } \\
\text { samples }\end{array}$ & $\begin{array}{c}\% \text { of } \\
\text { samples }\end{array}$ & $\begin{array}{r}\text { No of } \\
\text { samples }\end{array}$ & $\begin{array}{r}\% \text { of } \\
\text { samples }\end{array}$ \\
\hline
\end{tabular}

\begin{tabular}{cccccccc}
\hline & \multicolumn{3}{c}{ Low } & \multicolumn{2}{c}{ Medium } & \multicolumn{2}{c}{ High } \\
\hline 1. & $\mathrm{OC}$ & 47 & 62.67 & 20 & 26.67 & 8 & 10.66 \\
2. & $\mathrm{~N}$ & 72 & 96 & 3 & 4 & 0 & 0 \\
3 & $\mathrm{P}$ & 1 & 1.34 & 35 & 46.66 & 39 & 52 \\
4 & $\mathrm{~K}$ & 3 & 4 & 47 & 62.66 & 25 & 33.34 \\
$\mathbf{5}$ & $\mathrm{S}$ & 3 & 4 & 22 & 29.34 & 50 & 66.66 \\
\hline
\end{tabular}


Table.6 Correlation between physico-chemical properties and available macro nutrients in the soil of Narayanpur block

\begin{tabular}{llllll}
\hline & & $\mathbf{N}$ & $\mathbf{P}$ & $\mathbf{K}$ & $\mathbf{S}$ \\
\hline $\mathrm{pH}$ & .048 & .74 & .224 & -0.113 \\
$\mathrm{EC}$ & .195 & .031 & -.096 & .097 \\
$\mathrm{BD}$ & .078 & -.174 & .118 & -.061 \\
$\mathrm{PD}$ & -.107 & -.195 & $.235^{*}$ & .080 \\
$\mathrm{OC}$ & .022 & -.155 & .026 & -.121 \\
\hline
\end{tabular}

Positively non-significant correlation with $\mathrm{pH}$ and EC. Jatav and Mishra (2013) have also reported the similar results in soil of Mewar region of Rajasthan and Janjgir (2012) district of Chhattisgarh.

Available Potassium was found positively Significant correlation with Particle density $\left(\mathrm{r}=235^{*}\right)$ and Non-significant correlation with $\mathrm{P}^{\mathrm{H}}(\mathrm{r}=.224)$, Bulk density $(\mathrm{r}=.118)$, Organic Carbon (r=.026). The Potassium in soil Negatively Non- significant Correlation with EC. Similar relationship was also noticed by Chauhan (2001).

Available sulphur in these soil show negatively significant correlation relationship with $\mathrm{pH}(\mathrm{r}=-.113)$, Bulk density $(\mathrm{r}=.061)$, Organic Carbon (r=-.121). Positively correlation with EC and Particle density, these results corroborate the finding of Meena et al., (2006) positive correlation $(\mathrm{r}=0.051)$ of organic carbon and available sulphur. This relationship was existed because of most of the sulphur is associated with organic matter.

It can be concluded that the soil from Narayanpur block of Mirzapur district is categorized under neutral to moderately saline and alkaline in reaction. Organic carbon is low in range in the soils of studied area. About, $97 \%$ of soil samples found in medium available nitrogen, available phosphorus found medium (37\%) to high (67\%) and available potassium also recorded in similar range. Among the secondary macronutrient, available $\mathrm{S}$ noticed medium (44\%) to high (56\%) and exchangeable calcium, magnesium found sufficient in range.

\section{Acknowledgements}

The authors are highly grateful to the Head of Department of Soil Science and Agricultural Chemistry, Institute of Agricultural Sciences, Banaras Hindu University Varanasi for providing necessary facility to carry out this work.

\section{References}

Black, C.A. 1965. Soil Plant relationship 2nd edition New York., Pub. USA, pp. 515516.

Chauhan, J.S. 2001. Fertility status of soils of Birla Panchayat Samiti of Jodhpur district, Rajasthan. Master's thesis, MPUAT, Udaipur.

Chesnin, L. and Yien, C.H. 1951. Turbidimetric determination of available sulphate. Soil Science Society of America Proceedings, 15: 149- 151.

Giri, J.D., Das, K. and Shyampura, R.L. 2002. Occurrence of gypsiferous and associated soils in Bikaner district of Rajasthan and evaluation of their land use from field pedogenic characteristics. J. Indian Society of Soil Sci., 50(2): 189-196.

Gupta, S., Mallick, T., Datta, J.K. and Saha, R.N. 2006. Impact of opencast mining on the soil and plant communities of 
Sonepur-Bajari opencast coal mine area, West Bengal, India. Vista in Geol., 5: 94-198.

Hanway, J. and Heidal, H. 1952. Soil analysis methods as used in Iowa State, College and Soil Testing Laboratory. Iowa Agriculture, 57: 1-31.

Jatav, G.K. and Mishra, V.N. 2012. Evaluation of soil fertility status of available $\mathrm{N}, \mathrm{P}$ and $\mathrm{K}$ in inceptisol of Baloda block of Janjgir district of Chhattisgarh. J. Progressive Agri., 3(1): 28-32.

Kartikeyan, K., Pushpanjali and Prasad, J. Soil fertility status of soybean (Glycine max L.) growing soils of Malwa plateau, Madhya Pradesh. J. Indian Soc. Soil Sci., 62(2): 170-178.

Klute, A. and Dirksen, C. 1986. Hydraulic conductivity of saturated soils. In method of soil Analysis, ed. A. Klute. American Society of Agronomy and Soil Science Society of America, Madison United States, 694-700.

Kumar, M. \& A.L. Babel. 2011. Available Micronutrient Status and Their Relationship with Soil Properties of Jhunjhunu Tehsil, District Jhunjhunu, Rajasthan, India J. Agri. Sci., Vol. 3, No. 2.

Lal, R. and Singh, B.R. 1988. Effect of soil degradation on crop productivity in East Africa. J. Sustainable Agri., 13(1): 1541.

Mathur, G.M., Deo, R. and Yadav, B.S. 2006. Status of zinc in irrigated North-West Plain soils of Rajasthan. J. Indian Society of Soil Sci., 54(3): 359-361.

Meena, H.B., Sharma, P.R. and Rawat, U.S. 2006. Status of macro-micronutrients in some soils of Tonk district of Rajasthan. J. Indian Society of Soil Sci., 54: 508 512.

Muhr, G.R., Datta, N.P., Subramany, N.S., Dever, F., Lecy, V.K. and Donahue,
R.R. 1965. Soil testing in India, USDA, Publication, 120.

Nigam, G.K., Pandey, V.K., Tripathi, M.P. and Sinha, Jitendra. Assessment of macro and micro nutrients of soil in a small Agricultural watershed. Int. J. Chem. Tech. Res., 6(7): 3658-3664.

Olsen, S.R., Cole, C.V., Watanabe, F.S. and Dean, L.A. 1954. Estimation of available phosphorus in soil by extraction with sodium by carbonate. Circular 939, 1-19. U.S. department of Agriculture: Washington DC.

Pranagal, J. and Chmielewska, E.P. 2012. Physical properties of a Rendzicphaeozem during a ten year period of following under the condition of South-Eastern Poland. Geoderma, 189- 190: 262-267.

Pulakeshi, H.B.P., Patil, P.L., Dasog, G.S., Radder, B.M., Bidari, B.I. and Mansur, C.P. 2012. Mapping of nutrient status by geographic information system (GIS) in Mantagani village under northern transition zone of Karnataka. Karnataka J. Agri. Sci., 25(3): 332-335.

Salami, B.T. and Sangoyomi, T.E. 2013. Soil fertility status of cassava field in SouthWestern Nigeria, America. J. Experiment Agri., 3(1): 152-164.

Sharma, R.P., Yadava, R.B., Lama, T.D., Bahadur, A. and Singh, K.P. 2013. Status of secondary nutrients vis-a-vis soil site-characteristics of vegetable growing soils of Varanasi. Vegetable Sci., 40(1): 65-68.

Singh, R.P. and Mishra, S.K. 2012. Available macro nutrients (N, P, K and $\mathrm{S}$ ) in the soils of Chiraigaon block of district Varanasi (U.P.) in relation to soil characteristics. Indian J. Scientific Res., 3(1): 97-100.

Singh, Y.V., L.K. Jat, Santosh, K. 2015. Available Macro Nutrient Status and their Relationship with Soil PhysicoChemical Properties of Sri Ganganagar 
District of Rajasthan, India, J. Pure and Appl. Microbiol., Vol. 9(4), p. 28872894.

Somasundaram, J., Singh, R.K., Parandiyal, A.K., Ali, Shakir, Chauhan, V., Sinha, Nishant K., Lakaria, Brij L., Saha, R., Chaudhary, R.S., Coumar, M. Vassanda, Singh, R.K. and Simaiya, R.R. 2013. Soil Properties under different land use systems in parts of Chambal region of Rajasthan. J. Agri. Physics, 13(2): 139-147.

Subbiah, B.V. and Asija, G.L. 1956. A rapid procedure for estimation of available nitrogen in soil. Curr. Sci., 25: 259-260.
Verma, V.K., Patel, L.B., Toor, G.S. and Sharma, P.K. 2005. Spatial Distribution of Macronutrients in Soils of arid tract of Punjab, Indian. J. Agri. Biol., 7(2): 370-372.

Walkey, A. and Black, I. 1934. Armstrong. An examination of the Degtjareff method for determining soil organic matter and a proposed modification of the chromic acid titration method. Soil Sci., 37(1): 29-38.

\section{How to cite this article:}

Bharteey, P.K., Y.V. Singh, P.K. Sharma Sukirtee, Maneesh Kumar and Avinash Kumar Rai. 2017. Available Macro Nutrient Status and their Relationship with Soil Physico-Chemical Properties of Mirzapur District of Uttar- Pradesh, India. Int.J.Curr.Microbiol.App.Sci. 6(7): 2829-2837. doi: https://doi.org/10.20546/ijcmas.2017.607.394 